\title{
The Impacts of Verbal Violence by Family Members on Children's Social Emotional Aspects
}

\author{
Hendra Wahyuni, Yatim Riyanto, I Ketut Atmadja \\ Department of Non-Formal Education \\ Universitas Negeri Surabaya \\ Surabaya, Indonesia \\ yatimriyanto@unesa.ac.id
}

\begin{abstract}
The research is aimed to know the impact of violence verbal carried members of the family of the aspects of social emotional children aged early $2-4$. With the approach to study the case with methods of qualitative found that violent verbal in children aged early majority do mothers with an age, angry exaggeration, understatement, compare and threats. The cause of mother doing verbal among them: factor of economic, educational, rage against the couple as well as how to view the parents, of the children and factors environment. Impacts on children's emotional social aspects: a) intensity of violence around, imitated by children and difficult to be dammed by parents, b) always must be number one, c) instructive, d) aggressive and sensitive, e) difficult to succumb to, f) dependence on high mother. When members of the family often yell, children also perform on other people even dare to yell at people of his own as well as loss of independence and a sense of trust themselves children. So, the level of emotional social maternity of family members is very influential on the development of emotional social aspects of children of age religious.
\end{abstract}

Keywords—verbal violence; social emotional; family; children

\section{INTRODUCTION}

The survey results stated that the number of violence against children reached $47 \%$. Based on the recapitulation and survey of acts of violence against children, verbal violence is still rarely studied, while children are very vulnerable to acts of domestic violence. They are often victims. This happens because the child is in a weak position. Based on this background, the researcher finally decided that the title of this thesis was "The impacts of verbal violence by family members on Children's social emotional aspects".

Based on the background [1] of the problem above, the focus of the research is: a) how do forms of verbal violence be carried out by family members, b) how is the social emotional development of children aged 2-4, c) factors that cause verbal violence by family members to aspects social emotional early childhood ages 2-4 and d) the impact of verbal violence on the development of the emotional aspects of early childhood 2-4 years.

\section{A. Forms of Verbal Violence.}

The pattern of violent behavior carried out by family members actually inherits the pattern and culture of violence on children. Unconsciously, our speech can be very painful for children and make children angry or hold grudges against us. The category of verbal violence according to [2] is highpitched, cursing, labeling negative (the fool, the ugly etc.) insinuating.

\section{B. Emotional Social Development of Early Childhood 2-4 years.}

Child's social and emotional development is an emotional condition and the child's ability to respond to their environment [3]. At the initial emotional development stage, the division of emotions into 2 classifications [4], namely: a) Primary emotions, namely, basic emotions that arise in humans and also animals and b) conscious emotions, namely, emotions that require cognition, especially self-awareness Children aged 2-4 years have begun to recognize and express their feelings and begin to be able to express their feelings and independence.

The ability to recognize oneself in development from an early stage, especially sensitivity to increasing emotional development.

\section{Factors Causing Verbal Violence Performed by Family}

Members in Early Childhood 2-4 Years: Everything that causes verbal violence by family members in early childhood 2-4 years must be triggered by causes and events that make them do it lightly. All forms of violence that occur around children are caused by an imbalance in managing the emotions of adults around children. The existence of children as part of a weak community has the potential to become the target of verbal violence by family members.

\section{Impact of Verbal Violence on Early Childhood 2-4 Years}

All consequences of verbal violence against early childhood are fatal if the result is not known by family/ school members and the child does not get the appropriate treatment, so that the impact will certainly affect the growth and development of the child's life to adulthood.

Verbal violence experienced by children turned out to have a negative impact on the development of the child's next life. According to [2], that based on the results of the Carnegie Institute of Education study shows, $80 \%$ of children who enter elementary school have high self-confidence. However, when they are in the next level it drops dramatically. 


\section{METHOD}

The approach of this research results is relatively large using words, so the researcher uses a qualitative approach. Referring to [5]. This type of research is a type of case study, one of the types of approaches proposed by Creswell.

Data collection in this study uses instruments such as: 1) Human instruments, because they are considered to be more flexible and adaptable humans 2) field notes starting from the initial notes, development notes and additional notes, 3) Participant observation (Paticipant Observation) by involving themselves directly with the informants involved in the research arena, Openness of two important elements, namely the researcher and the researched (informant) about the purpose of the research needs to be built in order to know each other's interests [5].

TABLE I. INTERVIEW CHARACTERS FOR FAMILY MEMBERS

\begin{tabular}{l} 
Question Items with Verbal Violence Variables \\
\hline According to the mother, who among family members often \\
commits verbal violence in early childhood 2-4 years? \\
What do you think is violence? \\
Do you feel that you often abuse children? \\
How many times a day do you call your child by shouting or \\
yelling? \\
What nickname did you give your child when he did not obey \\
what you said? \\
Have you ever heard or read about verbal violence? \\
What causes you to do verbal violence? \\
Why are you sure you have to commit verbal violence to \\
children? \\
What do you feel after doing verbal violence against children? \\
What is the attitude / expression of your child after experiencing \\
verbal violence? \\
What understanding do you give your child when or after he \\
experiences verbal abuse that you do? \\
Do you know the consequences of verbal violence that are often \\
experienced by your child? \\
After you know a little about the effects of verbal violence that \\
are often experienced by your child, what efforts will you make \\
to reduce it?
\end{tabular}

Documentation [5] is an important record containing information from individuals, families and schools. Documentation can be in the form of shooting by researchers to strengthen research results. Validity criteria data that must be met in qualitative research in the opinion of [6] there are 4 basic provisions in order to guarantee the quality of qualitative research results, namely: Credibility (level of trust), dependence (dependency), confirmation, and transferability (transferability).

Data analysis techniques in this study, the data was taken at school and in the homes of students who showed indications of different behavior with their peers at school. The data analysis technique used in this study is to apply the stages as stated by [5].

\section{RESULTS AND DISCUSSION}

\section{A. Verbal forms of violence at home and at school}

Quote (1) : (in school)

DAHA : By the way, is your crew like yours? (what are you talking about?) (KV.Pen.a.1)

Child response: Shut up and accept

Context: Observations are carried out on Monday 18 March 2019 between 7:30 a.m. and 8:00 a.m. when the morning is at school. Suddenly Dafa said "bro, I asked you to tackle the bag, here are the words that are represented here, when you have an opo, your crew iki (what are you talking about ?!) ( KV.Pen.a.1).

Quote (1) represents the error (correction) of the work of the child and the opinion of the child and the blame for the results of the child's activities/ expressions.
Quote (2) : (at home)
D AHA : Why are you guys, doll toys? "There! a toy car is there with Dafa! (KV.Pen.a.2)

Child response: Shut up and accept

Context: The above quote is represented by parents on Tuesday March 192019 when children play at home (KV.Pen.a.2).

Excerpt (2) where parental speech is expressed through the use of words that mean blaming and underestimating the activities/ expressions of the child.

Quote (3) : (at home)

ADYUD : If you eat the rice should be none out of the plate, okay? (KV.Pen.a.1)

Child response: Impressive and seemingly ignoring

Context: The above quote is observed at home on March 20, 2019. Parents are represented when the child eats. (KV. Pen. A3)

Quotes (3) Parents blame children when eating because their eating method is not neat because a lot of rice is scattered and falls around the plate. Something similar is found in the following quote.

Quotes (4) SYAVI: He, how come the left hand is"! Come on, it's not pareng (while glaring and making a high note)

(KV.Pen.b.1).

Based on the results of the observation it was concluded that the forms of verbal violence, namely starting from rejection, inappropriate/ labeled expressions, expressions of excessive anger, comparing, reflecting/ degrading children to threatening

\section{B. Social emotional development of children aged 2 - 4}

The strength of each child in responding to and surviving environmental behavior is different. There are children who are strong enough to survive when they are victims of the environment, there are also children who are weak and 
vulnerable to environmental behavior. Easy crying is one indication that the child includes children who are weak towards behavior or reactions from the environment. Various reactions from the environment when the occurrence of verbal violence can vary, some are passive (not responding)/ silent, some are involved and also engage in verbal violence against children

\section{Child response: Shut up and accept}

Context: Presented by parents on March 26, 2019 at rest. The child takes food using his left hand. Parents do not want their children to take food using their left hand and there are speeches that Represents, how come the left hand is"! Come on, it's not allowed (while glaring and voicing with a high tone (KV.Pen.b.1).

\section{Factors that cause family members to verbal abuse}

Following are the results of interviews of researchers based on instruments with some parents about the factors that cause parents to commit verbal violence.

1) Recognition from student guardians that they often commit verbal violence to children, both at home and at school.

2) An imbalance between husband's income and household expenses is often the trigger for a husband and wife fight.

3) Husband's behavior which hurts his wife in a certain period (for example: infidelity) greatly affects the child.

4) The belief of parents that verbal violence is a good way to make children obey their parents.

5) The childhood experience of the mother/ father who was treated by his parents was applied to the child in the hope that his child would be much better than his parents.

6) People around the average child like to shout, use harsh and inappropriate words for children, so parents find it difficult to stem and children are influenced by the environment by imitating these habits.

7) Children are the property and responsibility of parents, both children are bad depending on parenting parents

8) The results of interviewing researchers with parents [7] classically through temporary interview activities can be underlined that, a series of verbal violence is influenced by several factors including (a) economy, (b) anger towards spouses, (c) parents' views about children (d) Ambitions of parents who want their children to be the best, (e) parenting parents and (f) the application of the same methods as those of past parents and $(\mathrm{g})$ social environment.

D. The impact of verbal violence by family members in early childhood 2-4 years.

The following are the results of interviews of researchers with the Mawar Putih playgroup educator who referred to the interview instrument with educators of the Mawar Putih playgroup institution directly.

The various behaviors shown by children in class include: a. If you joke loudly, if asked, the teacher tends to be quiet or answer with a very soft voice and always sleepy while at school (Dino).

b. Like to disturb friends, nosy and rude and seek attention with things that are not good. (Wild and Sakha) and when told tend to answer (reason and argue).

c. Overreacting when disturbed by friends / temperament (Zildan).

d. Easy to be angry, like to shout. (Zildan).

e. Every time you are asked to do something, always look for his mother for help. (Aditya) and Sauqia

The following are the results of interviews of researchers who refer to the instrument of interviewing parents of students from Mawar Putih playgroup in classics when parenting:

1) Good parents are those who are caring, patient and responsible.

2) The intensity of acts of verbal violence in children is very diverse, depending on the delinquency shown by the child.

3) Verbal violence that is usually done by parents is: yelling at children, yelling, belittling, threatening and comparing children.

4) A small part of parents understands the differences in physical violence and verbal violence.

5) Various reasons why parents are overly angry with children are because they are tired, children who cannot be told, fight with their husbands and so that children know they are afraid.

6) A small number of family members know the effects of verbal violence that they often do on children.

7) The majority of family members regret after verbal abuse of children.

8) Not many parents apologize to their children after they commit verbal violence, on average because they are not used to and prestige.

9) One of the motivations of parents to do verbal violence is because they want their children to be good children.

10) Past treatment of parents who are reapplied to their children now.

In this study, researchers also obtained data from the community leaders (Susi Handayani) the guardian of the Mawar Putih playgroup student who expressed her opinion during the interview, as follows:

From the experiences that I have experienced while I was waiting for school children, there were indeed a lot of negative things or words expressed by parents, a fellow child guard at school. That experience made me have to be aware to always say positive to children. The following is the result of interviewing researchers with educators and education staff at KB Mawar Putih based on interview instruments, namely: 
Teachers often find parents who like to compare, threaten and scream loudly at children.

\section{E. Profile of Forms of Verbal Violence}

In this section, the discussion of research findings in the field is in the form of forms of verbal violence, namely in the form of blame and rejection of children's activities, the use of phrases/ terms that are not suitable for children/ labeling, expressions of excessive anger and high pitch comparing children with other children, belittling and degrading children to threatening children [8]. Based on the results of interviews with participants, that which often does verbal violence with all its forms is "mother". The findings of the majority of forms of verbal violence are the type and quality of speech delivered by parents who tend to yell at children, use inappropriate words for early childhood, label, demean and threaten children [9].

Based on the results of observations concluded the forms of verbal violence include:

\section{Rejection of children's opinions / activities}

Rejection is the meaning of verbal expressions of adults (parents) against or disagreeing with what children say and do.

2. Use of language/ terms that are not suitable for children/ labeling

The use of language that represents a particular situation by taking terms commonly used by parents and relatively poorly understood by children, includes: a) analyzing/ likening children with objects or creatures that are in the picture of parents, b) labeling/ giving nicknames to children because the physical condition of children who have mass specifications: the fat, etc.

3. Daily language options that are not suitable for children. The use of language expressions that are not suitable for children. For example: say dirty words.

\section{Excessive anger expressions}

The expression of excessive anger is the act of saying aloud or yelling with insults, including: a) shouting and saying rude to the child, b) cursing the child accompanied by reproach in the form of excessive anger in the form of shouting or invective accompanied by reproach, c) Yelling at children.

5. Security is an expression.

6. Compare children with objects or other children.

7. Disparaging and demeaning children.

8. Threatening children.

F. Impact of Verbal Violence on Social Emotional Aspects of Early Childhood

From the observations, it was found that some of the main parts of the impact of verbal abuse on the development of social emotional aspects that occur in early childhood 2-4 years include:

\section{Social}

a. The intensity of violence that is often seen around is more easily imitated by children and difficult to be blocked by parents, for example: saying dirty (talking dirty, etc) ".

b. Children who show behavior must always be number one, bossy (instructive), aggressive, want to be earlier than their friends and difficult to succumb to are the result of the behavior of parents who often doctrine (making children as objects of desire).

c. The lack of confidence in children is due to the lack of space and opportunities for children to show their abilities.

\section{Emotional}

a. Emotional disorders in the form of children who are irritable (sensitive) and rude caused by the behavior of parents who like to scold children excessively.

b. When parents often yell at children, children tend to do the same thing to other people and even dare to yell at their own parents.

c. The loss of confidence in children to self-actualize (inferior) in building cooperation with their friends / other people.

Children aged 2-4 years with an inadequate level of emotional maturity often show a variety of spontaneous behaviors when they get verbal abuse [7], including: 1) silent and accepting, 2) ignorant (ignoring) and 3) rejecting / answering and giving reasons.

\section{CONCLUSION}

Family members who often commit verbal violence against early childhood are mothers, because the factors of emotional closeness and intensity of interaction are relatively close compared to other family members. The results of data analysis showed that verbal violence carried out by family members at home and at school had an impact on school learning and children's interactions with those around them [3]. The choice of parenting greatly affects the style and pattern of interaction between family members and early childhood.

The impact of verbal violence experienced by children directly and spontaneously in the form of changes in expression due to discomfort, but also there is a long-term impact that is felt by the child including the social impact and emotional impact that is relatively permanent and influences all aspects of child development. The impact of verbal violence on early childhood 2-4 years will be permanent if there is no intense and complete treatment, considering that the age of 2-4 years is the golden age of the child's field.

Family education in the form of parenting activities is a real effort in order to educate and open the horizons of family members to improve the quality of education and family coaching far better. 


\section{REFERENCES}

[1] Daniel Fincke . 2014. Verbal Abuse Inhibits Brain Development. ( http://www.patheos.com/blogs/camelswithhammers/2013/01/researchsuggests-verbal-abuse-hinders-brain-development/

[2] Megawangi , Ratna . 2011. Categories of verbal violence . Jakarta: Indonesia Heritage Foundation. Help . 2007 . All Rooted in Characters . Jakarta: FE UI Publishing Board

[3] Daniel Goleman. 2016. Emotional Intelligence . Jakarta: Gramedia.

[4] Terry E Lawson. 2007. https // journal.uny.ac.id /indeks.php.jpa/article

[5] Moleong, J, Lexy.2011. Qualitative Research Methodology. Bandung: PT. Teenager Rosdakarya.
[6] Ryan, Kevin \& Bohlin, Karen E. (1999). Building Character in Schools: Practical Ways to Bring Moral Instruction to Life. San Francisco: Jossey Bass

[7] Gootman. 2003. Caring for children and adolescents Godoy, Julia dan Loomans, Diana. 2007. Positive Parenting. Jakarta: PT Bhuana Ilmu Populer.

[8] Sujana Djuju, 1990. The Role of Families in the Community Environment, in Muslim Families in Modern Societies, Bandung: Rosyda Youth Works

[9] Nadia. 2004. https://www.academia.edu/29190600/Hak Asasi Manusia. about the loss of confidence due to verbal violence 